\title{
Trend of Public Emotions on Social Media Towards Study at Home Policies
}

\author{
Abdul Bashith ${ }^{1}{ }^{*}$ Waluyo Satrio Adji ${ }^{2}$, Arbain Nurdin ${ }^{3}$ \\ 1,2,3 Universitas Islam Negeri Maulana Malik Ibrahim Malang \\ *Corresponding author. Email: waluyo.satrio.adji@uin-malang.ac.id
}

\begin{abstract}
The Ministry of Education and Culture's response to COVID 19 is a policy of learning at and from home. The response of sentiments and public emotions to the learning policy at home is diverse and can be seen from social media, especially Twitter. Knowing the sentiments and public emotions of Twitter users over home study policies is the aim of this study. Quantitative approaches are used in this study. Data collection from Twitter in this study uses a big data system Drone Emprit Academic by giving the Keyword \#belajardirumah; learn from home. The one-month data limit is from April 1 to April 29, 2020. The results showed the volume of conversations received 88,389 is the total mention of Twitter about learning at home. Sentiment analysis showed $41 \mathrm{k}$ or $46 \%$ expressed negative sentiment, while positive sentiment was $44.2 \mathrm{k}$ or $50 \%$, and $3.2 \mathrm{k}$ or $4 \%$ stated neutrally. Expression The highest emotion arising from the public response from the learning policy at home is anger. Anger arises due to the many tasks, internet quota, application usage, hack data on the application.
\end{abstract}

Keywords: Emotion, Learning At Home, Pandemic, Covid-19

\section{INTRODUCTION}

The new case of the number of victims infected with the Covid 19 virus in Indonesia is increasingly worrying. Data from the task force for handling covid 19 in Indonesia [1]. October $3-2020$ there were the number of positive cases 299,506, healed 225,052, died 11,055. According to Luhut Binsar Panjaitan as Deputy Chair of the Committee for Handling Covid-19 and National Economic Recovery to handle the spread of Covid-19 in nine provinces, stated at a virtual press conference that the transmission of covid in September had increased due to undisciplined society [2].

The response from the Ministry of Education and Culture since 9 March 2020 issued the Minister of Education and Culture Circular Letter Number 3 of 2020 concerning Prevention of COVID-19 in the Education Unit, and Number 36962 / MPK.A / HK / 2020 concerning Online Learning and Working from Home in the Context of Prevention Spread of Corona Virus Disease (COVID-19), as well as Circular and Instructions from Regional Heads and Chancellors of each University [3].

Online learning is learning using interactive media on the basis of the internet that is used between teachers and students. In its development, online learning brings its own pros and cons for those who implement it, there are two kinds of views related to the learning revolution on the one hand the emergence of educational investment [4][5]. On the negative side, the unpreparedness of human resources can be stated that they still need technical assistance, training and direction in facing online learning.[6] The scope of the above journal articles and bulletins is not sufficient to draw conclusions about the effectiveness and ineffectiveness of online learning.

Therefore, it is necessary to observe broadly about the analysis of public sentiment, especially Twitter users, on learning during the Covid 19 pandemic. Sentiment analysis or text mining analysis was chosen to help academics understand the social opinion of every activity carried out or policy implementation. Several studies use sentiment analysis to see public responses such as 
sentiment analysis towards Indonesian presidential candidates [7].

The selection of Twitter as primary data is because data from Kominfo [8] that Twitter was chosen as a measure because of the development according to 2019, daily active users on Twitter were the largest in the world, for Indonesia the number reached 63 million.

Data released by Hotsuite We Are Social on January 2018 showed that the number Indonesian residents who use the internet as many as 132.7 million users or about $51 \%$ of the total population of Indonesia [9]. This data showed accelerated growth in internet users Indonesia which is significant. In 2014 APJII released data on internet users in Indonesia for 107 Million users and predicted growth Indonesian internet users are very significant on the coming years [10]. Therefore, the classification of public comment data on Twitter on online learning based on sentiment is beneficial for educators, researchers, society and policy makers.

\section{METHOD}

A quantitative approach is used in this research. One of the characteristics of a quantitative approach is that it can generalize about social phenomena that occur[11]Collecting data from Twitter in this study using a big data system called Drone Emprit Academic, by providing the keyword \#Belajardirumah; Learn from home. This big data system uses Twitter's API (Applications Programming Interface) to capture conversations in semi-realtime via the streaming method [12].

The scraping data from each post on Twitter is then classified, clustered, and the next calculation is analyzed by the existing system on Drone Emprit Academic. This type of research is also carried out related to Social Network Analysis with the help of software such as that done by Mahdi Shiddieqy and Dodie Tricahyono using Gephi software version 0.9.1[13] Made Kevin Bratawisnu, Andry Alamsyah (Social Network Analysis for Social Media User Interaction Analysis regarding Ecommerce Business. [14] Another study, Talbot, Acheampong and Wicentowski, who used SemEval2015, used the Sentiment Lexicon. The duration of the observation was one week between March 22 - April 2020.[15]

\section{RESULT AND DISCUSSION}

The first step taken by the researcher was to create a project on the website at UII academic emprit drone (https://dea.uii.ac.id/), which will then be connected to the dashboard https://academic.droneemprit.id/. In accordance with the research method, the results were obtained related to home learning. Obtained some data as shown in figure 1.

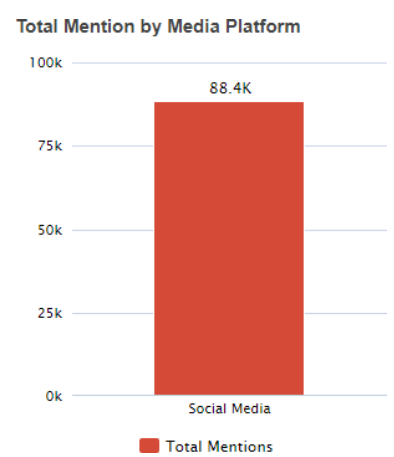

Figure 1. Volume Conversation Volume

Conversations between 1 - 29 April 2020, obtained 88,389 are the total mentions of twitter about studying at home.

\subsection{Emotional Trends towards Home Study Policy}

A number of emotions were impressed by the public on the learning atmosphere at home. Emotional analysis conducted by the system at Drone Emprit Academic uses Plutchink's Wheel of Emotions or "Plutchik's Wheel of Emotions" model. In theory, it is divided into 8, namely: joy, trust, fear, surprise, sadness, disgust, anger, and anticipation. The Emprit Drone category uses the "lexicon" method. Emotions are shown in figure 2.

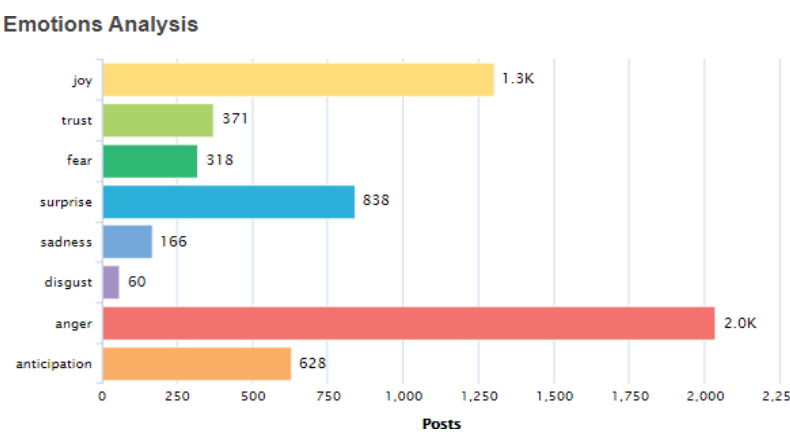

Figure 2. Emotions Analysis

\subsubsection{Joy}

The diagram above shows joy or joy over the study at home policy with the number of posts of $1.3 \mathrm{k}$. If you browse the conversation, you will get the data shown in table 1 . 
Table 1. Conversation of joy

\begin{tabular}{|c|c|}
\hline No. & Conversation \\
\hline 1 & $\begin{array}{l}\text { Twitter: @ outtaxspace Location: Han } 29 \\
\text { / Apr / } 202021: 38 \text { WIB } \\
\text { @ seollie_ Thank God then, Ma'am. Miss } \\
\text { Ralienka should eat more foods that contain } \\
\text { iron, huh! Don't forget to take medication if } \\
\text { you have anemia relapse. Not bad, today is } \\
\text { quite fun considering that tomorrow I will } \\
\text { not have online lectures, } \\
\text { Hehehe. Ma'am yourself? Negative Joy }\end{array}$ \\
\hline 2 & $\begin{array}{l}\text { Twitter: @ Ssaltedegg 29/Apr / } 2020 \\
\text { 21:28 WIB } \\
\text { @ moscacinoo Do you get scolded if you } \\
\text { study online? So want me } \\
\text { wkwk Neutral Joy }\end{array}$ \\
\hline 3 & $\begin{array}{l}\text { Twitter: @isengdoangsi } 29 \text { / Apr / } 2020 \\
19: 49 \text { WIB } \\
\text { @ohmybeautybank even when I like this I } \\
\text { take a shower in the morning, just before } \\
\text { fasting, take a shower, set } 8 \text { hours before } \\
\text { studying online, all the skincare when I'm } \\
\text { fasting like this when I wake up at } 9 \text { (there } \\
\text { are uts) when I'm not rushed or lazy, I'm } \\
\text { ready to take a shower + skincare, still on } \\
\text { midnight skincarean, at noon don't forget to } \\
\text { finish } \\
\text { prayer using ss lg Positive Joy }\end{array}$ \\
\hline 4 & $\begin{array}{l}\text { Twitter:@ @atgvvrl Location: Mars } \\
\text { 29/Apr / } 202014: 14 \text { WIB } \\
\text { @ Roughestneckkk I love going to college } \\
\text { online I like my job Positive Joy }\end{array}$ \\
\hline 5 & $\begin{array}{l}\text { Twitter: @ sjfxgurl Location: Taynew's son } \\
29 \text { / Apr / } 202014: 11 \text { WIB } \\
\text { @ Bbrightluvwin it's nice to study in class } \\
\text { too ... until I missed the online class once } \\
\text { I'm late on Google } \\
\text { classroom } 2 \\
\text { really lazy because the schedule is not clear } \\
\text { so hadehh } \\
\text { Negative Joy }\end{array}$ \\
\hline
\end{tabular}

\subsubsection{Trust}

The second form of emotion is trust, based on the results of data analysis it was found that the public discussed the theme of learning at home with an emotional level of confidence of 371 conversations, including the ones shown in table 2.
Table 2. Confidence Conversations

\begin{tabular}{|c|c|}
\hline No. & Conversation \\
\hline 1 & $\begin{array}{l}\text { Twitter: @ outtaxspace Location: Han } 29 \\
\text { / Apr / } 202021: 38 \text { WIB } \\
\text { @ seollie_ Thank God then, Ma'am. Miss } \\
\text { Ralienka should eat more foods that contain } \\
\text { iron, huh! Don't forget to take medication if } \\
\text { you have anemia relapse. Not bad, today is } \\
\text { quite fun considering that tomorrow I will } \\
\text { not have online lectures, } \\
\text { Hehehe. Ma'am yourself? Negative Joy }\end{array}$ \\
\hline 2 & $\begin{array}{l}\text { Twitter:@Ssaltedegg 29/Apr / 2020 } \\
\text { 21:28 WIB } \\
\text { @ moscacinoo Do you get scolded if you } \\
\text { study online? So want me } \\
\text { wkwk Neutral Joy }\end{array}$ \\
\hline 3 & $\begin{array}{l}\text { Twitter: @isengdoangsi } 29 \text { / Apr / } 2020 \\
\text { 19:49 WIB } \\
\text { @ ohmybeautybank even when I like this I } \\
\text { take a shower in the morning, just before } \\
\text { fasting, take a shower, set8 hours before } \\
\text { studying online, all the skincare when I'm } \\
\text { fasting like this when I wake up at } 9 \text { (there } \\
\text { are uts) when I'm not rushed or lazy, I'm } \\
\text { ready to take a shower + skincare, still on } \\
\text { midnight skincarean, at noon don't forget to } \\
\text { finish } \\
\text { prayer using ss lg Positive Joy }\end{array}$ \\
\hline 4 & $\begin{array}{l}\text { Twitter:@ batgvvrl Location: Mars } \\
\text { 29/Apr / } 202014: 14 \text { WIB } \\
\text { @ Roughestneckkk I love going to college } \\
\text { online I like my job Positive Joy }\end{array}$ \\
\hline 5 & $\begin{array}{l}\text { Twitter: @ sjfxgurl Location: Taynew's son } \\
29 \text { / Apr / } 202014: 11 \text { WIB } \\
\text { @ Bbrightluvwin it's nice to study in class } \\
\text { too ... until I missed the online class once } \\
\text { I'm late on Google classroom } 2 \\
\text { time wow really lazy } \\
\text { because the schedule is not clear so hadehh } \\
\text { Negative Joy }\end{array}$ \\
\hline
\end{tabular}

\subsubsection{Fear}

The third emotion is described in the form of fear seen from several public conversations about home study policies, among these conversations are shown in table 3. 
Table 3. Conversation Fear

\begin{tabular}{|c|c|}
\hline No. & Conversation \\
\hline 1 & $\begin{array}{l}\text { Twitter: @ dinashafila } \\
\text { Bandung, Indonesia 28 / Apr / } 2020 \text { 11:47 } \\
\text { WIB } \\
\text { If this is just a rough calculation, studying at } \\
\text { home until the end of the year, I don't know } \\
\text { that the new teaching has moved to January } \\
\ldots \\
\text { Shadow of Negative Fear }\end{array}$ \\
\hline 2 & $\begin{array}{l}\text { Twitter: @ishmaho } 28 \text { / Apr / } 2020 \text { 23:12 } \\
\text { WIB } \\
\text { It's crazy that I don't hear the chairman of } \\
\text { the mosque in ilc ngmg 'this corona is God's } \\
\text { creation, when we are afraid, especially } \\
\text { when we want to go to a holy mosque, the } \\
\text { house of Allah' I'm afraid I'm thinking about } \\
\text { the congregation of the mosque, what if the } \\
\text { chairman is like this Example of the results } \\
\text { of studying religion } \\
\text { inaccurate Negative Fear }\end{array}$ \\
\hline 3 & $\begin{array}{l}\text { Twitter: @ Wahyukusdinal1 } 28 \\
\text { / Apr / } 202020: 18 \text { WIB } \\
\text { RT [cm] This is my laptop, I'm afraid. why } \\
\text { is this my windows? because on the lower } \\
\text { right there is no writing again, even though } \\
\text { it used to be. I'm afraid that this window } \\
\text { ends, I can't } \\
\text { lecture on line friends help } \\
\text { please do my assignments all there is } \\
\quad \text { here. thanks. } \\
\text { https://t.co/CpktNawYWI } \\
\text { collegemenfess] } \\
\text { Negative Fear }\end{array}$ \\
\hline 4 & 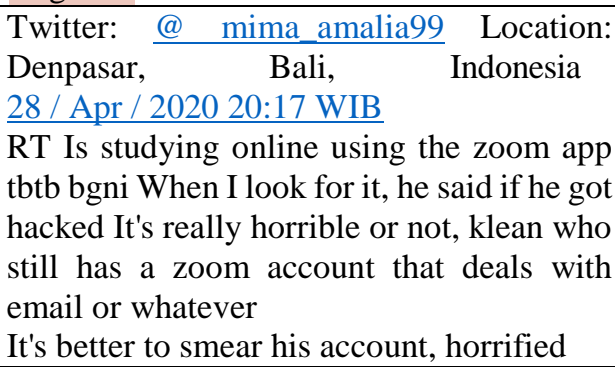 \\
\hline
\end{tabular}

\subsubsection{Surprise}

The fourth emotion is surprise, which can be seen in the analysis diagram showing that there are 838 posts, including the ones shown in table 4 .
Table 4. Conversation Surprise

\begin{tabular}{|c|l|}
\hline No. & \multicolumn{1}{|c|}{ Conversation } \\
\hline 1 & $\begin{array}{l}\text { Twitter: @ RakhaMauln 29 / Apr / 2020 21:28 WIB } \\
\text { while studying at home I also knew, it turns out } \\
\text { me do not know What" }\end{array}$ \\
\hline 2 & $\begin{array}{l}\text { Positive Surprise } \\
\text { Twitter: @ deniatmojoo Location: Central Java, } \\
\text { Sukoharjo 29/ Apr / 2020 20:59 WIB } \\
\text { Dilit completes the exam, get ready to be shocked } \\
\text { karo } \\
\text { hasile online lectures. Positive }\end{array}$ \\
\hline 3 & \begin{tabular}{l} 
Twitter: @ Retweeted 29 / Apr / 2020 20:58 WIB \\
Sometimes you are surprised to see lecturers \\
during online study who say like "Every Student \\
Don't Chat with Me, Because There are Many \\
Student Contacts on My Cellphone" So, What \\
About Us Students? Who Should Help Parents \\
Work, But 2x Tasks \\
Charged to Us. \\
Negative Surprise \\
\hline 4
\end{tabular} \\
$\begin{array}{l}\text { Twitter: @ acupofcheesetea Location: ravenclaw } \\
\text { dorm. 29 / Apr / 2020 20:49 WIB } \\
\text { @txtdrindomy oh so you rarely go online, learn to } \\
\text { huh? } \\
\text { Negative Surprise }\end{array}$ \\
\hline
\end{tabular}

Emotions of surprise, there was a spike on April 13 and 14, 2020, if traced there is a policy from the Governor of Central Java, Mr. Ganjar Pranowo, who prepared the Tomb of Heroes for the medical team. This has received a lot of retweets posted by brother Azzam M Izzulhaq or @ AzzamIzzulhaq, with the content of the post "My wife is busy cooking, teaching the children to study, cleaning the house, washing, ironing, etc. Then we whisper tenderly in her ear:“ Honey, you are great. Your struggle is extraordinary. I have prepared the best burial ground for you ". Jago tah mun teu digaplok I perform !.

The figure 3 shows the conversation trends on April 13 and $14,2020$.

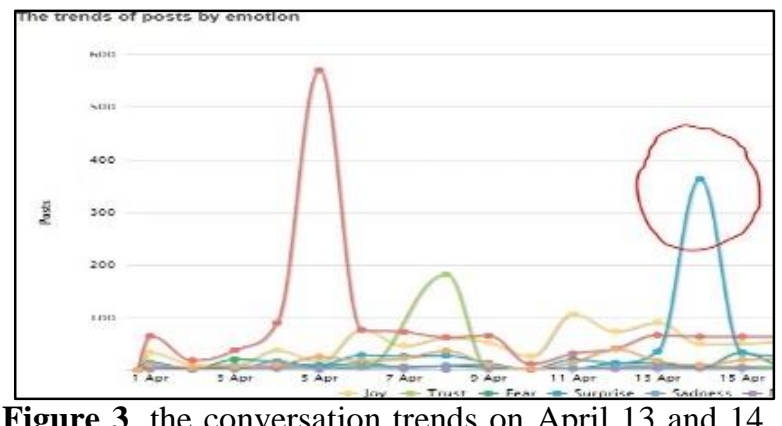

Figure 3. the conversation trends on April 13 and 14 2020. 


\subsubsection{Sadness}

The fifth emotion is sadness with the study at home policy, the data obtained by as many as 166 posts are as shown in table 5 .

\section{Table 5. Conversation of Sadness}

\begin{tabular}{|c|c|}
\hline No. & \\
\hline \multirow[t]{2}{*}{1} & $\begin{array}{l}\text { @ successful Location: Indonesia 29 / Apr / } \\
\frac{202021: 34 \text { WIB }}{\text { tired already thinking where i'm real }} \\
\text { the material from the online video has just } \\
\text { finished spending time, studying too late "this } \\
\text { is not regular :( so sad, oh my God }\end{array}$ \\
\hline & Negative \\
\hline 2 & $\begin{array}{l}\text { Twitter:@endang_yl } \\
\text { 19:19 WIB } \\
\text { Rabb .... cheap really. How farmers } \\
\text { don't cry on bombay. I, who only studied } \\
\text { Nanem in the garden at home, was sad to know } \\
\text { this price }\end{array}$ \\
\hline 3 & $\begin{array}{l}\text { Twitter: @ safiradivaaa 29 / Apr / } 2020 \text { 18:40 } \\
\text { WIB } \\
\text { sad if you think about it, the last year of college } \\
\text { can make you meet friends before returning to } \\
\text { your home but it's not good, this is the condition } \\
\text { miss } \\
\text { really jogging Positive Sadness }\end{array}$ \\
\hline 4 & $\begin{array}{l}\text { Twitter: @ schfess Location: School Canteen } 29 \\
\text { / Apr / } 202018: 32 \text { WIB } \\
\text { Sch! It's so sad that on May 02 I want to } \\
\text { announce graduation but online, almost } 2 \\
\text { months I don't see friends even though I say } \\
\text { goodbye, because later I will be busy studying, } \\
\text { working and looking for a sad identity. Is there } \\
\text { the same? } \\
\text { Negative Sadness }\end{array}$ \\
\hline 5 & $\begin{array}{l}\text { Twitter: @ himitsunotsuki } 29 \text { / } \\
\text { Apr / } 202016: 48 \text { WIB } \\
\text { @avocadcoffee Choking is a task, because } \\
\text { offline lectures are really killing tasks ... So } \\
\text { online lectures like this there is plenty of time to } \\
\text { read references, the lecturers if you want to add } \\
\text { assignments are also sorry ... read the weekly } \\
\text { paper } 2000 \text { words / students might add more } \\
\text { thick glasses } \\
\text { if you add an assignment. Negative Sadness }\end{array}$ \\
\hline
\end{tabular}

\section{Table 6. Conversation Disgusted}

\begin{tabular}{|c|c|}
\hline No. & Conversation \\
\hline 1 & $\begin{array}{l}\text { Twitter: Location: Indonesia } 29 / \mathrm{Apr} / 2020 \\
20: 12 \text { WIB } \\
\text { The risk of a house near the runway is when the } \\
\text { online lecture suddenly loses the network by } \\
\text { the plane } \\
\text { fighter flashed. Already disrupting the } \\
\text { network, too noisy. } \\
\text { Negative Disgust }\end{array}$ \\
\hline 2 & $\begin{array}{l}\text { Twitter: @ Angell08896579 Location: Japan } \\
\text { 29/Apr / } 202008: 55 \text { WIB } \\
\text { : absence of fertilization at the core of the } \\
\text { institution, causing seeds to be produced } \\
\text { outside. What are examples of forestry plants? } \\
\text { : (confidently) teak bu ... } q \text { : wkwkwkwkwk } \\
\quad: \text { Since when teak it } \\
\text { Gymnosperms. : lecture on line morning:( } \\
\text { hate le } \\
\text { Negative Disgust }\end{array}$ \\
\hline 3 & $\begin{array}{l}\text { Twitter:@ Usanguyun1 } 28 \text { / Apr / } 2020 \\
\text { 22:37 WIB } \\
\text { I am grateful to study online, thanks to that I } \\
\text { am not very clueless } \\
\text { because Lots Duty individual } \\
\text { Negative Disgust }\end{array}$ \\
\hline 4 & $\begin{array}{l}\text { Twitter: @ devinofitasa Location: Mojokerto, } \\
\text { East Java } 28 \text { / Apr / } 2020 \text { 22:15 WIB } \\
\text { Can WhatsApp delete all the posts online Like } \\
\text { to be annoyed seeing gabales } 2 \text { people even } \\
\text { though they are online "Yes, who knows, reply } \\
\text { to others first" Yes, who knows, who knows, or } \\
\text { online lecture or the end of the chat or really } \\
\text { don't want to reply } \\
\text { Negative Disgust }\end{array}$ \\
\hline 5 & $\begin{array}{l}\text { Twitter: @_morning sun 27 / Apr / } 2020 \text { 11:04 } \\
\text { WIB } \\
\text { hate bgt online college, panic wake up } \\
\text { Negative Disgust }\end{array}$ \\
\hline
\end{tabular}

\subsubsection{Anger}

The diagram above shows the highest anger or anger over the policy of studying at home with the number of posts of $2.0 \mathrm{k}$. If you browse the conversation, you can get words shown in table 7 .

\subsubsection{Disgust}

The diagram above shows disgust with the policy of studying at home with a total of 60 posts. If you browse the conversation, it can be as shown in table 6 : 
Table 7. Angry Conversation

\begin{tabular}{|c|l|}
\hline No. & \multicolumn{1}{|c|}{ Conversation } \\
\hline 1 & $\begin{array}{l}\text { Twitter:@ tawonwie, Location: } \\
\text { Thailand 29/ Apr / 2020 21:34 WIBOnline } \\
\text { lectures taught me to do multitasking badly. } \\
\text { The left ear is for listening neatly, the right } \\
\text { ear for listening to songs so I'm not crazy, } \\
\text { left hand typing activity reports, right hand } \\
\text { doing tasks } \\
\text { kimor. already crazy. Negative }\end{array}$ \\
\hline 2 & $\begin{array}{l}\text { Twitter:@laithningstorm } \\
\text { Shaman, Indonesia 29 / Apr / 2020 20:57 } \\
\text { WIB }\end{array}$ \\
$\begin{array}{l}\text { Nonetheless, preferring to enter the ordinary } \\
\text { rather than online lectures. There are not } \\
\text { online lectures but online assignments } \\
\text { Positive Anger }\end{array}$ \\
\hline 3 & $\begin{array}{l}\text { Twitter:@gngbgz } \\
\text { Denpasar, Bali, 29 / Apr / 2020 19:39 WIB } \\
\text { @onecak I swear I'm getting annoyed too. my } \\
\text { sister studied at home, you have to take a } \\
\text { photo from him. no guarantee } \\
\text { the sincerity of the Negative Anger's oath }\end{array}$ \\
\hline 4 & $\begin{array}{l}\text { Twitter: @ zahra_jasmine, 29 / Apr / 2020 } \\
\text { 19:12 WIB } \\
\text { Online lectures may just be dead until } \\
\text { December } \\
\text { rmh Negative Anger }\end{array}$ \\
\hline
\end{tabular}

\subsubsection{Anticipation}

The diagram above shows the highest anger or anger over the policy of studying at home with the number of posts of $2.0 \mathrm{k}$. If you browse the conversation, you can get the words shown in table 8 .

Table 8. Anticipatory Conversation

\begin{tabular}{|c|c|}
\hline No. & Conversation \\
\hline \multirow[t]{3}{*}{1} & $\begin{array}{l}\text { Twitter: @ Smpnk Location: Indonesia } \\
29 \text { / Apr / } 2020 \text { 17:26 WIB }\end{array}$ \\
\hline & $\begin{array}{l}\text { \#Study at home } \\
\text { until } 30 \text { May 2020. Continue to limit } \\
\text { outdoor activities, keep your distance, } \\
\text { health and hygiene. Hopefully } \\
\text { always healthy. https://t.co/x9xRZBDwtE }\end{array}$ \\
\hline & \begin{tabular}{|l|l} 
Positive & Anticipation
\end{tabular} \\
\hline \multirow[t]{2}{*}{2} & $\begin{array}{l}\text { Twitter:@Enangee } \\
\text { 13:22 WIB } \\
\text { May this pandemic disappear quickly and } \\
\text { go to college. The thing is I don't want to } \\
\text { fight absent } \quad \text { on line }\end{array}$ \\
\hline & Anticipation \\
\hline 3 & $\begin{array}{l}\text { Twitter: @ocation: } \\
\text { Surabaya City, East Java 29 / Apr / } 2020 \\
\text { 21:40 WIB } \\
\text { RT Hidup is sawang sinawang, there are } \\
\text { those who work and get regular salaries but } \\
\text { are far from home and even can't go home. } \\
\text { There are also those who are still in college, }\end{array}$ \\
\hline
\end{tabular}

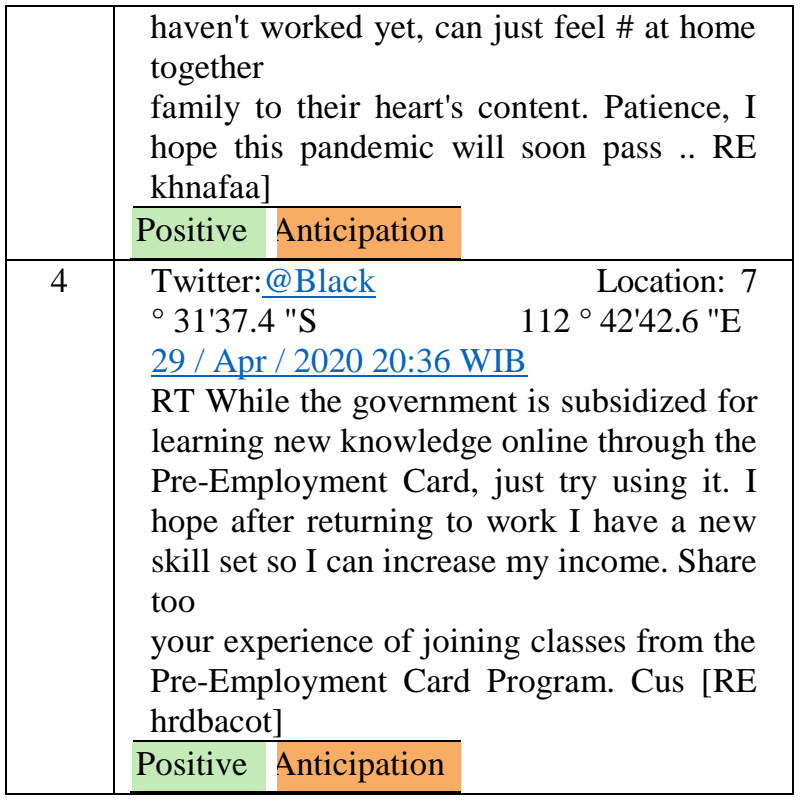

\section{CONCLUSION}

The total volume of conversations from mentions from twitter about study at home policies was 88,389. The highest trend of emotional expression that arises as a result of the public response to the home study policy is anger. Anger arises due to the large number of tasks, internet quota, application usage, hacking data on applications. Surprise surged as of April 14 due to the response to the Central Java Governor's statement regarding the policy of the hero graves for the medical team.

\section{REFERENCES}

[1] "Beranda | Satgas Penanganan COVID-19." https://covid19.go.id/ (accessed Oct. 04, 2020).

[2] "Luhut: Kasus Covid-19 Naik karena Masyarakat tidak Disiplin | Republika Online."https://republika.co.id/berita/qguuul409 /luhut-kasus-covid19-naik-karena-masyarakattidak-disiplin (accessed Oct. 04, 2020).

[3] K. P. dan K. R. Indonesia, "Pencegahan Corona Virus Disease (COVID-19) Pada Satuan Pendidikan." pp. 1-5, 2020, Accessed: Oct. 04, 2020. [Online]. Available: https://setjen.kemdikbud.go.id/setjen/files/SE Nomor 3 Tahun 2020 tentang Pencegahan Corona pada satuan pendidikan.pdf.

[4] N. L. Khusniyah and L. Hakim, P "Efektivitas Pembelajaran Berbasis Daring: Sebuah Bukti Ada Pembelajaran Bahasa Inggris," J. Tatsqif, vol. 17, no. 1, pp. 19-33, Jul. 2019, doi: $10.20414 /$ jtq.v17i1.667.

[5] E. Kuntarto, "Keefektifan Model Pembelajaran Daring Dalam Perkuliahan Bahasa Indonesia Di Perguruan Tinggi," J. Indones. Lang. Educ. Lit., 
vol. 3, no. 1, pp. 99-110, Dec. 2017, doi: 10.24235/ileal.v3i1.1820.

[6] Yulia Indahri, "Permasalahan Pembelajaran Jarak Jauh Di Era Pandemi," Pusat Penelitian Badan Keahlian DPR R, pp. 13-18, Jun. 2020.

[7] F. Nurhuda, S. W. Sihwi, and A. Doewes, "Analisis Sentimen Masyarakat terhadap Calon Presiden Indonesia 2014 berdasarkan Opini dari Twitter Menggunakan Metode Naive Bayes Classifier," vol. 2, no. 2, 2013.

[8] Kominfo, "Kominfo: Pengguna Internet di Indonesia 63 Juta Orang," Website Resmi Kementeri. Komun. dan Inform. RI, 2013.

[9] H. we are social, "Indonesia Digital Landscape," Special reports digital in 2018: world's internet users pass the 4 billion mark, 2018. .

[10] APJII, “Internet User Profil Pengguna in Indonesia 2014," 2014.
[11] Sugiyono, Metode Penelitian Kuantitatif, Kualitatif dan R \& D.Bandung:Alfabeta. 2012.

[12] I. Fahmi, "Drone Emprit: Konsep dan Teknologi," IT Camp on Big data and Data Mining, Jakarta, 2017. .

[13] M. S. Setatama and D. Tricahyono, Ir., M.M., Ph.D., "Implementasi Social Network Analysis pada Penyebaran Country Branding 'Wonderful Indonesia,"' Indones. J. Comput., 2017, doi: 10.21108/indojc.2017.2.2.183.

[14] K. M. Bratawisnu and A. Alamsyah, "Social Network Analysis Untuk Analisa Interaksi User Dimedia Sosial Mengenai Bisnis E-Commerce," J. Manaj. Dan Bisnis Vol., 2018.

[15] R. Talbot, C. Acheampong, and R. Wicentowski, "SWASH: A Naive Bayes Classifier for Tweet Sentiment Identification," 2015, doi: $10.18653 / \mathrm{v} 1 / \mathrm{s} 15-2104$. 